Article

\title{
Analysis of the Impact of Different Variables on the Energy Demand in Office Buildings
}

\author{
José Luis Fuentes-Bargues ${ }^{1, * \mathbb{D}}$, José-Luis Vivancos ${ }^{1}$, Pablo Ferrer-Gisbert ${ }^{1} \mathbb{D}$ and \\ Miguel Ángel Gimeno-Guillem ${ }^{2}$ \\ 1 GIDDP, Departamento de Proyectos de Ingeniería, Universitat Politècnica de València, Camino de Vera s/n, \\ 46022 Valencia, Spain; jvivanco@dpi.upv.es (J.-L.V.); pferrer@dpi.upv.es (P.F.-G.) \\ 2 School of Industrial Engineering, Universitat Politècnica de València, 46022 València, Spain; \\ migigui1@etsii.upv.es \\ * Correspondence: jofuebar@dpi.upv.es; Tel.: +34-96-387-7000 (ext. 85651)
}

Received: 10 June 2020; Accepted: 28 June 2020; Published: 1 July 2020

\begin{abstract}
The design of near zero energy offices is a priority, which involves looking to achieve designs which minimise energy consumption and balance energy requirements with an increase in the installation and consumption of renewable energy. In light of this, some authors have used computer software to achieve simulations of the energy behaviour of buildings. Other studies based on regulatory systems which classify and label energy use also generally make their assessments through the use of software. In Spain, there is an authorised procedure for certifying the energy performance of buildings, and software (LIDER-CALENER unified tool) which is used to demonstrate compliance of the performance of buildings both from the point of view of energy demand and energy consumption. The aim of this study is to analyse the energy behaviour of an office building and the variability of the same using the software in terms of the following variables: climate zone, building orientation and certain surrounding wall types and encasements typical of this type of construction.
\end{abstract}

Keywords: building energy certification; energy efficiency measures; office buildings; near zero energy buildings

\section{Introduction}

Climate change is one of the main priorities for government policy and the field of scientific research. One of the causing factors of climate change is high levels of energy consumption, as residential and commercial areas account for between 20 and $40 \%$ of total energy consumption in developed countries [1]. As a result, the International Energy Agency (IEA) states in its reports that buildings must be the main focus for the reduction of energy consumption [2-4]. The European Union in response to the Kyoto Protocol has fixed the so-called "20-20-20" objectives as an objective for 2020, for which member states should reduce their emissions of greenhouse gases by $20 \%$ with respect to 1990 levels, increase the proportion of renewable resources used in the production of energy by $20 \%$ and reduce the consumption of primary energy through a $20 \%$ increase in energy efficiency [5]. These objectives have been further widened in the 2021-2030 Climate and Energy Framework (Framework 2030) [6] establishing as key objectives at least $40 \%$ cuts in greenhouse gas emissions, at least a $32 \%$ share for renewable energy in energy consumption and a 32.5\% improvement in energy efficiency with regard to 1990 levels, thus implementing the EU's commitments under the Paris Agreement [7].

These objectives have been formalised for the construction industry by way of various regulations. Firstly, Directive 2002/91/CE [8], related to the energy efficiency of buildings, was the first regulatory requirement which comprehensively tackled the problem of energy consumption in buildings. The next step was Directive 2010/31/UE [9], later reinforced by Directive 2012/27/UE [10], which established 
a framework for a general methodology for calculating energy efficiency in buildings and certain minimum energy efficiency requirements applicable to both new buildings and already existing buildings. What is more, this Directive requires that all new buildings (residential, offices and services) constructed in the European Union from 2020 be near zero energy, promoting the improvement of thermal insulation, the production of onsite renewable energy and the installation of high energy efficiency equipment.

In 2018, Directive 2018/844/EU [11] was enacted to increase efforts to achieve the Horizon 2030 commitments. This Directive sets the achievement of complete and homogeneous building insulation as one of the basic priorities for achieving energy savings in buildings. This would maintain an adequate temperature in indoor spaces, eliminate problems of humidity and condensation and also achieve better indoor air quality and lower thermal input requirements. Among other aspects, the use of highly energy-efficient air-conditioning systems and the installation of recharging stations for electric vehicles in buildings are also encouraged, as well as an improvement in the transparency of energy efficiency certificates.

This new regulatory framework has made the design of near zero energy buildings a priority, both for academia and for the professional sector [12], with the aim of achieving designs which minimise energy consumption and which balance energy requirements with an increase in the installation and consumption of renewable energy [13].

Buildings play a very important part in the overall energy demand of Spain. In 2014, their energy consumption represented $29.7 \%$ of total final energy demand and $62.2 \%$ of total electricity demand, which is not very different from that of all EU buildings (38.5\% and $58.8 \%$, respectively) [14].

Service sector buildings, which include offices, commerce, health, education, hotels and restaurants, accounted for $11.1 \%$ of total final energy consumption in Spain in 2014 [14]. Office buildings accounted for approximately $40 \%$ of the energy consumed in this sector [15]. On the other hand, heating and cooling consumption respectively account for $30 \%$ and $25 \%$ of the consumption of an average office in Spain [15], which justifies the importance of reducing its energy demand.

In Spain, in addition to new regulations, various programmes have been developed to encourage energy saving in buildings. One of these was the PAREER-CRECE Programme (Programme of Aids for the Energy Renovation of Existing Buildings), developed between 2013 and 2016, which aimed to promote actions for existing buildings of any use that would favour energy savings, improve energy efficiency, reduce $\mathrm{CO}_{2}$ emissions and take advantage of renewable energies, expressly excluding the construction of new buildings. This programme provided $120,696,809$ euros in aid, $86 \%$ of which was allocated to actions affecting the thermal envelope of buildings [15].

Much of the research has been based on software which simulates the energy behaviour of buildings using tools such as Energy Plus, TRNSYS and ESPr o DOE2 [16,17], while other research has been based on regulatory systems of energy classification and labelling and its associated software [18-20].

In Spain, with the ratification of the Technical Code for Building [21], IT tools were developed in order to demonstrate compliance of the building's behaviour from the point of view of energy demand (LIDER) and from the point of view of energy consumption (CALENER) [22]. Aparicio-Ruiz et al. in the application of the SEDICAE methodology used the LIDER tool to calculate the energy demand of model buildings. In this case, they studied four types of single-family housing (a detached house, semi-detached house, terraced house and back-to-back terraced house) [23] and a three-floored single-family house [13], and carried out the simulation for twelve different climate zones in Spain.

In the methodology they used, the initial simulation of the different types of housing in the different climate zones showed that both the annual demand for heating and cooling of the terraced house type of housing demonstrated lower energy demand in all climate zones. The simulation also showed how for all types of housing, greater heating demand was required for zones D1 and E1, and lower demand for zones A3 and A4. For cooling, zones C1, D1 and E1 had zero demand and the greatest demand was required by zones $\mathrm{A} 4, \mathrm{~B} 4$ and $\mathrm{C} 4$. 
With the transposition of the EU Directive 2012/27/EU to Spanish regulations in line with the Royal Decree $235 / 2013$, by way of which the process for certifying the energy performance of buildings was ratified [24], the two software applications were unified into a single unified software called the "Herramienta Unificada LIDER CALENER" or LIDER-CALENER Unified Tool (HULC) [25].

Rosselló-Batle et al. [26] carried out a study of several types of residential housing in the Balearic Islands, where they studied the relationship between incorporated demand and thermal energy demand, using HULC to calculate the latter.

Three types of housing were studied: a single-family detached house (two floors), a terraced house and a duplex in a multi-storey house. In the case of both the terraced house and the duplex, the West and East facing facades shared dividing walls with adjacent buildings. The first simulations that the authors carried out showed that simply changing the type of single-family house from a detached house to a terraced house led to a reduction of close to 40 and $45 \%$ in energy demand for heating and cooling, respectively, and in the case of the duplex, the reduction was $77 \%$ and $50 \%$, respectively.

For the terraced house, the greatest reductions in annual heating demand were obtained with a change from an inclined roof to a flat roof and with the use of external insulation in the façades. As for cooling demand, the greatest reductions were achieved by using extruded polystyrene (XPS) and polyurethane foam (PUR) insulation panels in the ceramic tile façades. In the case of the duplex, the greatest reductions in both annual heating and cooling demand was obtained with the use of PUR panels in the exterior walls.

Other authors like Sánchez-Ramos et al. [27] used the HULC tool as a first step of a methodology to develop simplified models of energy behaviour of buildings calibrated by way of data originating from real data concerning air pressure, thermal transition values (U-value) and electricity consumption bills.

In all the above mentioned studies, the case studies have focussed on single-family housing of diverse types, and no simulation was carried out for other types of buildings where energy demand might be greater, like hospitals, commercial buildings or administrative offices, both in the public or private sector [18-20]. On the other hand and as the authors of the official HULC tool themselves indicate: "There are quite a few publications developing its use" [27]. In view of this, and focussing on the typology of administrative buildings, the aim of this study is to analyse the energy behaviour of a building using the HULC tool to consider its climate zone, the building orientation and the insulation types typical of this type of construction. This is intended to provide the project architect or engineer with quick guidelines for selecting construction elements in order to comply with energy demand limitations subject to the climate zone of the site, avoiding the need to carry out numerous simulations.

This work presents the research method, then a case study is analysed of a two-storey administrative building adjacent in one of its facades to an industrial building housing a production system or storage space. We present and discuss the principal results of the research and the main contribution the research can provide, along with the limitations of the study and possible future lines of research.

\section{Methodology}

The methodology employed for the analysis of the energy demand compliance of an administrative building subject to its climate zone, building orientation and surrounding wall and encasement types typical of this type of construction was structured in accordance with Figure 1. 




Figure 1. Research method.

The first step of the methodology is to define the geometry of the building. In order to construct the model of the building, we used the Spanish ratified tool for assessing energy demand of new-build buildings, the "Herramienta Unificada LIDER-CALENER (HULC)". For this purpose, we used version 1.0.1564.1124 from March 2017 [25].

Once the thermal characteristics of the building envelope have been defined, other characteristics of the building are determined: thermal bridges, type of rooms/premises (habitable or non habitable), level of thermal conditioning of the rooms/premises, the level of ventilation and the usage profile.

The rooms/premises shall be identified as habitable or non habitable (e.g., equipment rooms), as well as whether thermal conditioning requirements are necessary. For example, storage rooms used for an administrative activity will be habitable but not air conditioned.

In relation to thermal bridges, the Support Document DA DB HE-3 [28], identifies an atlas of possible thermal bridges of a building, identifying for each of them the level of linear thermal transmittance. In the HULC program, the thermal bridges of all the building joints is identified: facade pillars, hollow jambs and lintels, slab fronts, etc., as well as their length.

Adequate ventilation of buildings ensures that no humidity or condensation will form, affecting the quality of the indoor air. Ventilation flows are set for homes using the DB HE 3 Indoor air quality [29] and for administrative buildings in the RITE [30]. The renovation flow rate can be determined by various methods, either indirectly, such as the surface area of the premises or the occupancy of the premises, or directly from the building's pollution load. In this case, ventilation corresponding to $45 \mathrm{~m}^{3} / \mathrm{h} /$ person has been considered, resulting in 0.9 renovations/hour in buildings.

The referred DB HE-1 [29], also sets the maximum air permeability of the elements of the thermal enclosure as a function of the winter climate zone. In this case, an air permeability of $25 \mathrm{~m}^{3} / \mathrm{h} \mathrm{m}^{2}$ was considered for the windows, lower than the maximum level permitted.

The second step is to define the construction elements of each of the enclosed areas which make up the building and, in each case, their facades, indicating their thickness and thermal properties. To this end, a habitual constructive composition associated with industrial buildings is used as a starting point. This construction composition is described in Section 3, corresponding to the case study.

The characteristic techniques for the construction elements are based on the Construction Elements Catalogue from the Technical Code for Building [31]. This catalogue was an initiative of the Ministry of Development in collaboration with the Catalonian Institute of Building Technology 
(ITeC) [32] and includes information concerning the individual characteristics of the materials and the construction elements, and of their hygrothermal and acoustic behaviour. The calculation of the thermal transmittance of the building $(\mathrm{U})$ is carried out using the HULC programme following the specifications in the Basic Document DB HE-1 from the Technical Code for Building published by the Ministry of Development [33].

In the Spanish regulations, in the Basic Document DB HE 1 [29], there are some reference limit values of thermal transmittance of the building (U) for the building envelopes depending on each of the winter climate zones. This reference value can be used for an initial approximation, although the particular characteristics of the building envelope: the materials and openings, as well as the orientation and characteristics of the building itself condition the $U$ value necessary for compliance with the regulatory requirement.

The HULC-tool, as its name suggests, is a combination of the two tools (LIDER and CALENER) already in use in Spain. In order to calculate the demand for thermal energy of a building, the LIDER tool was used, providing a verification of the limits on energy demand established by the Technical Code for Building (CTE). This tool includes a graphic interface for a 3D representation of the building, and is based on an algorithm constructed in Spain by the AICIA Heat Engineering Group (University of Sevilla), allowing the user to define the geometry of the building and all its components. Within the tool, the location (meteorological data), the working timetable of the building and consigned temperatures are determined; the programme also carries out simulations of the timetable behaviour of the building, taking into account the presence of both thermal inertia and possible thermal bridges [34]. The simulation tool algorithm was validated by the International Energy Agency (IEA) comparing its results with results obtained by other internationally recognised tools, such as DOE2 or TRNSYS, obtaining results within the established range for the compared parameters [35].

This article focuses on the analysis of energy demand, leaving the study of consumption for further research. In line with Spanish regulations, the concept of "joint energy demand (for heating and cooling)" has been used. This is defined as the energy demand obtained as a weighted sum of the energy demand for heating (DH) and the energy demand for cooling (DC). It is expressed in $\mathrm{kWh} /\left(\mathrm{m}^{2}\right.$ year $)$, considering the usable area of the building's living spaces. The weighting is carried out according to the expression: $\mathrm{DJ}=\mathrm{DH}+0.70 \mathrm{DC}$. This means the energy required for lighting and DHW generation is not considered.

A standardised use profile of the building (internal loads) of medium intensity and $16 \mathrm{~h}$ has been used. This consists of use from Monday to Friday from 7 a.m. to 10 p.m., and Saturdays from 7 a.m. to 2 p.m., with the following characteristics:

Set-point for air conditioning: $25^{\circ} \mathrm{C}$, and for heating: $20^{\circ} \mathrm{C}$.

Sensitive occupation: $6 \mathrm{~W} / \mathrm{m}^{2}$

Latent occupation: $3.79 \mathrm{~W} / \mathrm{m}^{2}$

Equipment: $4.50 \mathrm{~W} / \mathrm{m}^{2}$

Ventilation: $100 \%$.

The third step is the analysis of the energy demand of the building modelled with the HULC tool in terms of the variables, which are based on location and orientation.

The location of the building is associated to a climate zone. The severity of the climate in winter and in summer together with exterior temperature and solar radiation have an impact on the energy demands of the building [33]. The Technical Code for Building defines the climate zone scale in Spain. Fifteen different climate zones are defined as the combination of the climate zones in winter which are assigned the letters A-E and the symbol $\alpha$, and of the four climate zones in summer, which are assigned the numbers 1-4. According to the scale defined by the Technical Code for Building, when two locations are found in the same climate zone, the energy demand for winter and summer for a similar building located in the two locations is more or less the same. In order to guarantee this, the CTE defines the climate zones in terms of the severity of the climate, which is subject to degree days and 
solar radiation [13]. In this study, the 15 climate zones in Spain (A3, A4, B3, B4, C1, C2, C3, C4, D1, D2, D3, E1, $\alpha 3$, A2 and B2) were analysed.

The building's orientation influences the number of solar radiation hours which the building receives and the behaviour of the building under its orientation (North, South, East and West) was analysed for each one of the climate zones, generating a total of 60 combinations for analysis (i).

These combinations are designated in terms of values: $C Z O$.

Where:

$\mathrm{CZ}$ is the climatic zone of Spain (A3, A4, B3, B4, C1, C2, C3, C4, D1, D2, D3, E1, 23, A2 and B2)

$\mathrm{O}$ is the orientation (N North, S South, E East and W West).

For each one of the sixty proposed combinations, and taking as a starting point the geometric and construction combinations of the building defined in steps 1 and 2, a simulation was carried out using the HULC tool to verify compliance with the limitations of energy demand.

The number of simulations is identified by way of the $\mathrm{j}$ variable, with each of the simulations labelled by way of the value $C Z O j$.

In cases where there is compliance with the conditions from the starting point, the simulation is identified as $j=1$. In the case of non-compliance, a process is started of varying the construction characteristics of the building. The proposed construction solutions are usually employed solutions for the construction of administrative buildings with similar characteristics to those of the initially defined building. Amongst those modifications which are introduced or proposed are the following: modification of the facade and encasements of the building (characteristics and thickness of the materials), modification of the characteristics of the spaces (characteristics of the framework, composition of the glass) and the use of slats in the windows to reduce the effects of the sun. The modifications of the construction characteristics are proposed individually, with a simulation using the HULC tool carried out for each modification, until the requirements of the energy demand regulations are met, identifying the simulation $j=n$ which achieves compliance with the regulations for each of the sixty alternatives.

In each $\mathrm{j}$ simulation carried out, the economic cost of the proposed modification was calculated. The cost was determined using the database of construction prices of the Valencia Institute of Building (IVE) for 2019 [36]. In order to make the economic comparison, it is necessary to indicate that the simulations start with climate zone B3 and a south-facing building orientation, corresponding to, amongst other locations, the city of Valencia.

\section{Case Study}

The building which is the object of the analysis has a surface area of $2215 \mathrm{~m}^{2}$ on its ground floor and first floor, its dimensions being $71.6 \mathrm{~m}$ in length and $14.6 \mathrm{~m}$ in width. It is a building designed for administrative use, attached by a dividing wall adjacent in one of its facades to an industrial building housing a production system and/or storage space. The building is used throughout a full morning and afternoon timetable. The reception, offices, an exhibition-conference room, technical rooms, changing rooms and relaxation areas for workers from the production area are located on the ground floor. On the first floor there are several work rooms, offices and archives connected with the administrative use of the building. The layout of the floors of the building can be seen in Figure 2 and the facades of the building in Figure 3.

This case study has been selected for several reasons. Firstly, because it is a very common type of building in the Spanish industrial sector, an administrative building attached to the production and/or storage warehouses, with one of its facades acting as a party wall. The second reason is that it is a large administrative building with many users, which influences the complexity of compliance with regulations. 



FIRST FLOOR



ROOF

Figure 2. Layout of the study building.


RIGHT FACADE

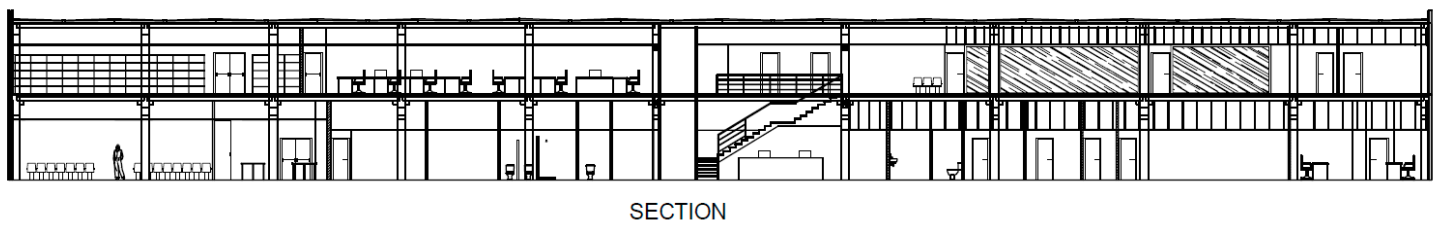

Figure 3. Facades and section of the study building.

Administrative buildings connected to industrial processes and/or storage usually have common or very similar construction characteristics. Regulatory fire protection requirements have promoted the use of prefabricated reinforced concrete structures and heavy outside walls constructed from reinforced concrete panels of varying thicknesses. These walls, for aesthetic reasons, are usually covered or combined with steel or aluminium panels. Another common characteristic is the spaces and 
openings in the walls which have a double objective, a functional effect of providing daylight to the interior and also an aesthetic effect. The layout of the spaces, given its need for versatility and speed of execution, is usually achieved using laminated plaster partitions, with thicknesses and support structures in accordance with the free height of the spaces and the acoustic and thermal requirements of the regulations and/or the promotors. The roofs are more varied, although one of the most common systems are inverted non walkable roofs, which allow for more or less insulation depending on the thermal needs of the climate zone where the building is located.

In Table 1, the characteristics of the construction elements of the model building are shown. It is a typical solution used in Spanish administrative buildings and provides a starting point for the simulations carried out in this study. The building modelled in the HULC tool is shown in Figure 4.

Table 1. Characteristics of the construction elements of the study building.

\begin{tabular}{|c|c|c|c|}
\hline Enclosure & $\mathrm{U}\left(\mathrm{W} / \mathrm{m}^{2} / \mathrm{K}\right)$ & Material Layers & $\begin{array}{l}\text { Thickness of } \\
\text { the Layers (m) }\end{array}$ \\
\hline Facades & 0.61 & $\begin{array}{l}\text { Prefabricated concrete panel of } 16 \mathrm{~cm} \text { thick, } \\
\text { covered on the inside with a } 5 \mathrm{~cm} \text { layer of } \\
\text { mineral wool insulation and a } 1.5 \mathrm{~cm} \text { layer of } \\
\text { laminated gypsum board and on the outside } \\
\text { with a composite panel made up of two } 1 \mathrm{~mm} \\
\text { thick aluminium cover sheets and a } 5 \mathrm{~mm} \\
\text { polystyrene core. }\end{array}$ & 0.232 \\
\hline $\begin{array}{l}\text { Party wall (with the } \\
\text { industrial building) }\end{array}$ & 0.78 & $\begin{array}{c}\text { Prefabricated concrete panel of } 20 \mathrm{~cm} \text { thick, } \\
4 \mathrm{~cm} \text { mineral rock wool insulation and } 1.5 \mathrm{~cm} \\
\text { laminated gypsum board backing }\end{array}$ & 0.255 \\
\hline Groundfloor & 0.44 & $\begin{array}{l}\text { A } 1.5 \mathrm{~cm} \text { stoneware slab, embedded with } \\
1.5 \mathrm{~cm} \text { of cement mortar, } 6 \mathrm{~cm} \text { of polystyrene } \\
\text { insulation between two layers of plastic } \\
\text { polystyrene, a } 10 \mathrm{~cm} \text { layer of reinforced } \\
\text { concrete together with plastic polystyrene } \\
\text { and } 10 \mathrm{~cm} \text { of sand and gravel. }\end{array}$ & 0.29 \\
\hline First floor slab & 2.29 & $\begin{array}{l}25 \mathrm{~cm} \text { hollow-core slab, a } 4 \mathrm{~cm} \text { cement mortar } \\
\text { and a } 2 \mathrm{~cm} \text { stoneware slab for support. }\end{array}$ & 0.31 \\
\hline $\begin{array}{l}\text { Internal partitioning } \\
\quad \text { (Type } 1)\end{array}$ & 0.45 & $\begin{array}{c}\text { Partition formed by two } 1.5 \mathrm{~cm} \text { laminated } \\
\text { plaster boards and } 6 \mathrm{~cm} \text { mineral wool } \\
\text { insulation }\end{array}$ & 0.09 \\
\hline $\begin{array}{l}\text { Internal partitioning } \\
\quad \text { (Type } 2)\end{array}$ & 0.66 & $\begin{array}{l}\text { Prefabricated concrete panel of } 16 \mathrm{~cm} \text { thick, } \\
\text { covered on the inside with a } 5 \mathrm{~cm} \text { layer of } \\
\text { mineral wool insulation and a } 1.5 \mathrm{~cm} \text { layer of } \\
\text { laminated gypsum board }\end{array}$ & 0.225 \\
\hline Roof & 0.45 & $\begin{array}{c}\text { Non-trafficable roof with an } 8 \mathrm{~cm} \text { layer of } \\
\text { sand and gravel, a } 6 \mathrm{~mm} \text { textile lining, } 6 \mathrm{~cm} \\
\text { of expanded polystyrene insulation, another } \\
6 \mathrm{~mm} \text { textile lining and a } 10 \mathrm{~cm} \text { cement } \\
\text { mortar for forming slopes }\end{array}$ & 0.252 \\
\hline $\begin{array}{l}\text { Door and window } \\
\text { glazing }\end{array}$ & 1.7 & $\begin{array}{l}\text { Double glazing of } 6 \mathrm{~mm} \text { thick, with a } 12 \mathrm{~mm} \\
\text { interior air chamber and low emission glass. } \\
\text { Solar factor of } 0.48\end{array}$ & 0.024 \\
\hline $\begin{array}{l}\text { Window and } \\
\text { doorframe }\end{array}$ & 2.20 & $\begin{array}{l}\text { Metallic frame with a thermal bridge break of } \\
\text { between } 4 \text { and } 12 \mathrm{~mm} \text {. The surface of the } \\
\text { frame with respect to the total of the window } \\
\text { of } 15 \% \text {. The air permeability will be half of } \\
\text { the maximum allowed, which is } 50 \mathrm{~m}^{3} / \mathrm{Hm}^{2} \text {. }\end{array}$ & \\
\hline
\end{tabular}




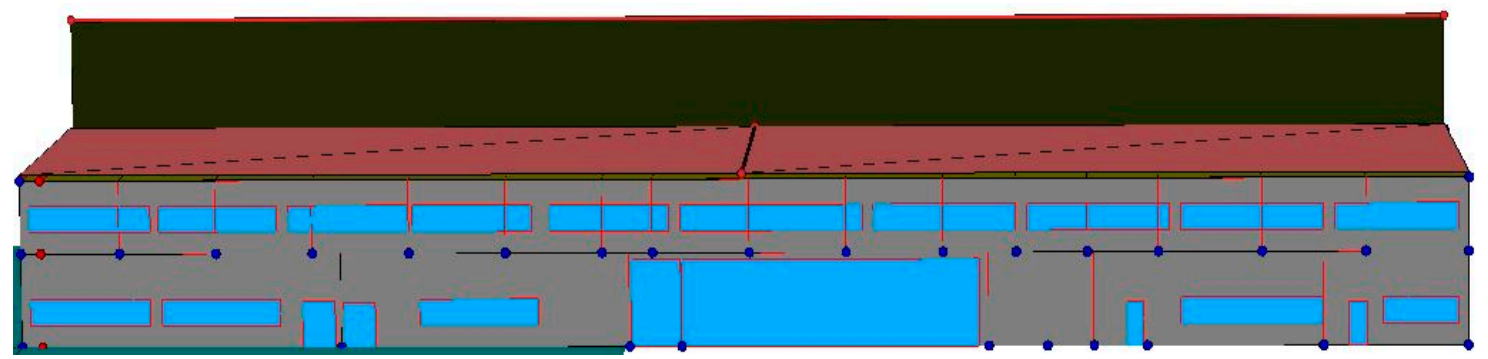

Figure 4. Model of the study building with the HULC tool.

In Table 2, the different measurements to be implemented are described. Only those modifications which are usually carried out on the structural typology in question have been considered, both in the case of the surrounding walls and roofs and in the interior spaces. The posterior facade of the building corresponds to the dividing wall it shares with the industrial space and, for construction reasons, no modifications have been contemplated for this wall.

Table 2. Characteristics of the improvements on the elements under consideration.

\begin{tabular}{|c|c|c|}
\hline Enclosure & $\mathrm{U}\left(\mathrm{W} / \mathrm{m}^{2} / \mathrm{K}\right)$ & Material Layers \\
\hline $\begin{array}{l}\text { Door and window } \\
\text { glazing }\end{array}$ & 1.4 & $\begin{array}{c}\text { Double glazing of } 6 \mathrm{~mm} \text { thick, with a } 16 \mathrm{~mm} \text { interior air chamber and } \\
\text { low emission glass. Solar factor of } 0.41\end{array}$ \\
\hline $\begin{array}{l}\text { Window and } \\
\text { doorframe }\end{array}$ & 2.2 & Polyvinyl chloride (PVC) frame \\
\hline Window slats (shadow) & & Horizontal slats $15 \mathrm{~cm}$ wide, $25 \mathrm{~cm}$ apart and inclined at $30^{\circ}$ \\
\hline \multicolumn{3}{|r|}{ Remove insulation (RI) } \\
\hline $\begin{array}{l}\text { Internal partitioning } \\
\quad \text { (Type 2) }\end{array}$ & 0.61 & $\begin{array}{l}\text { Prefabricated concrete panel of } 12 \mathrm{~cm} \text { thick, covered on the inside with a } \\
5 \mathrm{~cm} \text { layer of mineral wool insulation and a } 1.5 \mathrm{~cm} \text { layer of laminated } \\
\text { gypsum board }\end{array}$ \\
\hline Groundfloor & 2.39 & $\begin{array}{l}\text { A } 1.5 \mathrm{~cm} \text { stoneware slab, embedded with } 1.5 \mathrm{~cm} \text { of cement mortar, } \\
\text { a } 10 \mathrm{~cm} \text { layer of reinforced concrete together with plastic polystyrene } \\
\text { and } 10 \mathrm{~cm} \text { of sand and gravel }\end{array}$ \\
\hline \multicolumn{3}{|r|}{ Insulation improvement 1 (Ins 1) } \\
\hline $\begin{array}{l}\text { Internal partitioning } \\
\text { (Type 1) }\end{array}$ & 0.35 & $\begin{array}{l}\text { Partition formed by two } 1.5 \mathrm{~cm} \text { laminated plaster boards and } 10 \mathrm{~cm} \text { of } \\
\text { mineral wool insulation }\end{array}$ \\
\hline Roof & 0.36 & $\begin{array}{l}\text { Non-trafficable roof with an } 8 \mathrm{~cm} \text { layer of sand and gravel, a } 6 \mathrm{~mm} \\
\text { textile lining, } 8 \mathrm{~cm} \text { of expanded polystyrene insulation, another } 6 \mathrm{~mm} \\
\text { textile lining and a } 10 \mathrm{~cm} \text { cement mortar for forming slopes. }\end{array}$ \\
\hline Groundfloor & 0.36 & $\begin{array}{c}\text { A } 1.5 \mathrm{~cm} \text { stoneware slab, embedded with } 1.5 \mathrm{~cm} \text { of cement mortar, } 8 \mathrm{~cm} \\
\text { of polystyrene insulation between two layers of plastic polystyrene, } \\
\text { a } 10 \mathrm{~cm} \text { layer of reinforced concrete together with plastic polystyrene } \\
\text { and } 10 \mathrm{~cm} \text { of sand and gravel }\end{array}$ \\
\hline \multicolumn{3}{|r|}{ Insulation improvement 2 (Ins 2) } \\
\hline $\begin{array}{l}\text { Internal partitioning } \\
\text { (Type 1) }\end{array}$ & 0.24 & $\begin{array}{l}\text { Partition formed by two } 1.5 \mathrm{~cm} \text { laminated plaster boards and } 15 \mathrm{~cm} \text { of } \\
\text { mineral wool insulation }\end{array}$ \\
\hline Roof & 0.30 & $\begin{array}{l}\text { Non-trafficable roof with an } 8 \mathrm{~cm} \text { layer of sand and gravel, a } 6 \mathrm{~mm} \\
\text { textile lining, } 10 \mathrm{~cm} \text { of expanded polystyrene insulation, another } 6 \mathrm{~mm} \\
\text { textile lining and a } 10 \mathrm{~cm} \text { cement mortar for forming slopes. }\end{array}$ \\
\hline Groundfloor & 0.30 & $\begin{array}{c}\text { A } 1.5 \mathrm{~cm} \text { stoneware slab, embedded with } 1.5 \mathrm{~cm} \text { of cement mortar, } \\
10 \mathrm{~cm} \text { of polystyrene insulation between two layers of plastic } \\
\text { polystyrene, a } 10 \mathrm{~cm} \text { layer of reinforced concrete together with plastic } \\
\text { polystyrene and } 10 \mathrm{~cm} \text { of sand and gravel. }\end{array}$ \\
\hline
\end{tabular}


Table 2. Cont.

\begin{tabular}{|c|c|c|}
\hline Enclosure & $\mathrm{U}\left(\mathrm{W} / \mathrm{m}^{2} / \mathrm{K}\right)$ & Material Layers \\
\hline \multicolumn{3}{|r|}{ Insulation improvement 3 (Ins 3) } \\
\hline $\begin{array}{l}\text { Internal partitioning } \\
\quad \text { (Type 1) }\end{array}$ & 0.34 & $\begin{array}{l}\text { Partition formed by two } 1.5 \mathrm{~cm} \text { laminated plaster boards and } 10 \mathrm{~cm} \\
\text { mineral wool insulation, and an inner sheet of hollow ceramic brick. }\end{array}$ \\
\hline Roof & 0.26 & $\begin{array}{l}\text { Non-trafficable roof with an } 8 \mathrm{~cm} \text { layer of sand and gravel, a } 6 \mathrm{~mm} \\
\text { textile lining, } 12 \mathrm{~cm} \text { of expanded polystyrene insulation, another } 6 \mathrm{~mm} \\
\text { textile lining and a } 10 \mathrm{~cm} \text { cement mortar for forming slopes. }\end{array}$ \\
\hline Groundfloor & 0.26 & $\begin{array}{l}\text { A } 1.5 \mathrm{~cm} \text { stoneware slab, embedded with } 1.5 \mathrm{~cm} \text { of cement mortar, } \\
12 \mathrm{~cm} \text { of polystyrene insulation between two layers of plastic } \\
\text { polystyrene, a } 10 \mathrm{~cm} \text { layer of reinforced concrete together } \\
\text { with plastic polystyrene and } 10 \mathrm{~cm} \text { of sand and gravel }\end{array}$ \\
\hline \multicolumn{3}{|r|}{ Insulation improvement 4 (Ins 4) } \\
\hline $\begin{array}{l}\text { Internal partitioning } \\
\quad \text { (Type 1) }\end{array}$ & 0.24 & $\begin{array}{l}\text { Partition formed by two } 1.5 \mathrm{~cm} \text { laminated plaster boards and } 15 \mathrm{~cm} \\
\text { mineral wool insulation and an inner sheet of hollow ceramic brick }\end{array}$ \\
\hline Roof & 0.23 & $\begin{array}{l}\text { Non-trafficable roof with an } 8 \mathrm{~cm} \text { layer of sand and gravel, a } 6 \mathrm{~mm} \\
\text { textile lining, } 14 \mathrm{~cm} \text { of expanded polystyrene insulation, another } 6 \mathrm{~mm} \\
\text { textile lining and a } 10 \mathrm{~cm} \text { cement mortar for forming slopes }\end{array}$ \\
\hline Groundfloor & 0.23 & $\begin{array}{c}\text { A } 1.5 \mathrm{~cm} \text { stoneware slab, embedded with } 1.5 \mathrm{~cm} \text { of cement mortar, } \\
14 \mathrm{~cm} \text { of polystyrene insulation between two layers of plastic } \\
\text { polystyrene, a } 10 \mathrm{~cm} \text { layer of reinforced concrete together with plastic } \\
\text { polystyrene and } 10 \mathrm{~cm} \text { of sand and gravel }\end{array}$ \\
\hline \multicolumn{3}{|r|}{ Insulation improvement 5 (Ins 5) } \\
\hline $\begin{array}{l}\text { Internal partitioning } \\
\text { (Type 1) }\end{array}$ & 0.19 & $\begin{array}{l}\text { Partition formed by two } 1.5 \mathrm{~cm} \text { laminated plaster boards } \\
\text { and } 20 \mathrm{~cm} \text { mineral wool insulation, as well as } \\
\text { an inner sheet of hollow ceramic brick }\end{array}$ \\
\hline Roof & 0.20 & $\begin{array}{l}\text { Non-trafficable roof with an } 8 \mathrm{~cm} \text { layer of sand and gravel, a } 6 \mathrm{~mm} \\
\text { textile lining, } 16 \mathrm{~cm} \text { of expanded polystyrene insulation, another } 6 \mathrm{~mm} \\
\text { textile lining and a } 10 \mathrm{~cm} \text { cement mortar for forming slopes. }\end{array}$ \\
\hline Groundfloor & 0.21 & $\begin{array}{l}\text { A } 1.5 \mathrm{~cm} \text { stoneware slab, embedded with } 1.5 \mathrm{~cm} \text { of cement mortar, } \\
16 \mathrm{~cm} \text { of polystyrene insulation between two layers of plastic } \\
\text { polystyrene, a } 10 \mathrm{~cm} \text { layer of reinforced concrete together } \\
\text { with plastic polystyrene and } 10 \mathrm{~cm} \text { of sand and gravel }\end{array}$ \\
\hline
\end{tabular}

\section{Results and Discussion}

In this section, the results obtained are presented with an analysis of the number of simulations carried out in order to achieve compliance with the regulations, the measurements applied and the implementation cost of the same for each climate zone and building orientation. A total of 451 simulations have been carried out in this study in order to obtain compliance with the limits on energy demand. With the aim of achieving compliance with the lowest possible economic expenditure, we have endeavoured to use the lowest number possible of window slats due to their visual impact and their cost.

Figure 5 shows the number of $j$ simulations (ordered according to orientation) carried out in order to comply with the limit of energy demand in each climate zone and according to orientation. This $j$ value shows the difficulty in complying with the limit of energy demand, which varies for each climate zone and orientation. In general, an orientation facing South has been the most favourable, meaning a lower number of simulations, except for the case of climate zone D3, where the orientation does not impact on the number of simulations, and $\alpha 3$, where orientation $\alpha 3 \mathrm{~N}_{5}$ was the most favourable. Conversely, no one orientation provided more difficulty in achieving compliance than others, given that this is subject to the climate zone. 




Figure 5. Number of simulations per orientation.

Figure 6 shows the number of $\mathrm{j}$ simulations (ordered by climate zone) carried out in order to comply with the limit of energy demand in each climate zone and according to orientation. No one particular climate zone can be identified as the easiest for compliance with the energy demand regulations for the case study. The easier climate zones, that is, those requiring the least number of simulations, were B3 and B4, where, for each of the orientations, the number of $\mathrm{j}$ simulations has been less than 5 . Conversely, climate zones $\mathrm{C} 1$ and $\mathrm{C} 2$ have been where most difficulty was experienced in complying with the limits on energy demand. For example, in the case of climate zone $\mathrm{C} 1 \mathrm{~N}$, the number of simulations in order to achieve compliance was $\mathrm{j}=20\left(\mathrm{C}_{1} \mathrm{~N}_{20}\right)$. It was noted that $\mathrm{C} 1$ is an "intermediate" climate zone meaning that it does not have extreme summers or winters. The effect of this is that, despite their being a relatively small difference between the energy demand of the building in question and the limit on energy demand, it proved difficult to reduce the energy demand of the building. For this climate zone, the proposed measures have been to modify its insulation, changes in the windows and glass, shading by way of window slats and improvements in the carpentry.

Other actions that were simulated, like the removal of the floor insulation and changes to the prefabricated concrete of the façade, together with the modification of the windows and glass and the use of Polyvinyl chloride (PVC) frames, provided better results for energy demand than the initial construction plan, but still came up short in complying with the required demand.

Figure 7 shows the cost (in Euros) of the measures contemplated and assessed in order to achieve compliance with the limit of energy demand in each climate zone and by orientation against final energy demand $(\mathrm{kWh} / \mathrm{m} 2 /$ year). The positive values represent an additional cost, while a negative value represents a saving when achieving compliance. It can be observed that no relation exists between the final demand of the building $(\mathrm{kWh} / \mathrm{m} 2 /$ year $)$ and the cost of achieving compliance. In general, in warm and mild climate zones (A, B and C) the proposed measures have lead to cost savings; conversely, in colder climate zones ( $\mathrm{D}$ y $\mathrm{E}$ ) the measures have caused additional expenses. In the case of the climate zone/orientation E1 N10 the additional expenses rose to 64,040 €. In the D1 N9, D2 N9 and D2 O9 combinations there was an additional cost of more than 50,000€, which demonstrates the importance of orientation from an environmental and economic point of view. 


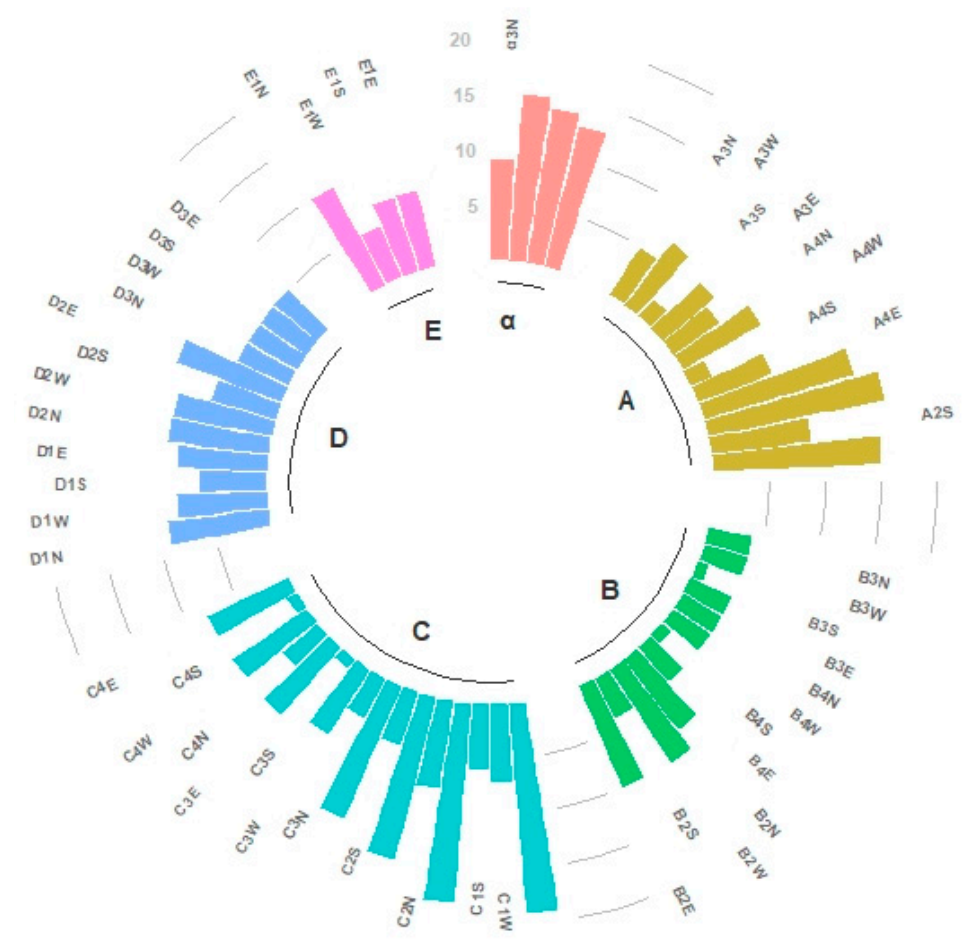

Figure 6. Number of simulations per climate zone.

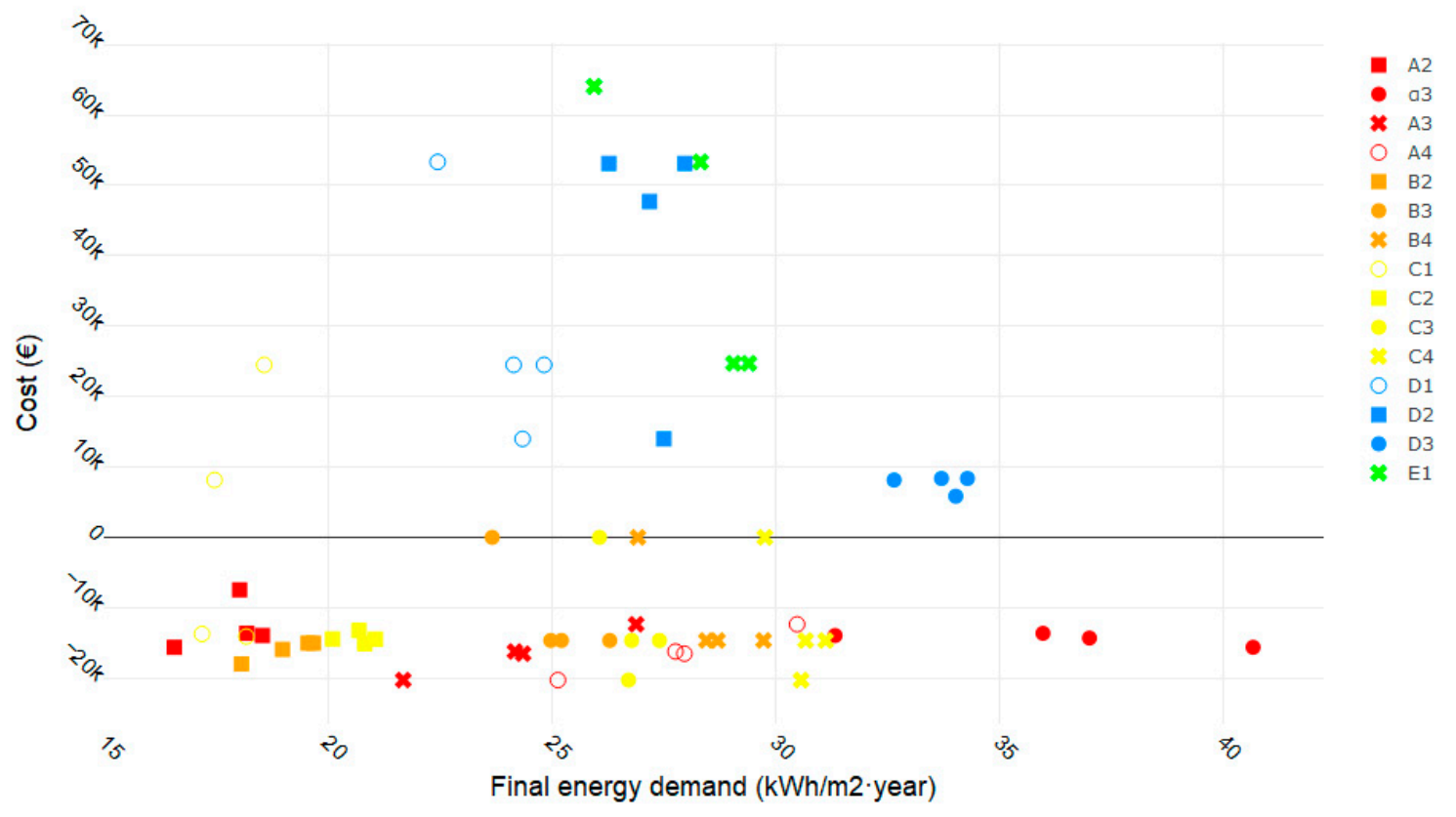

Figure 7. Cost $(€)$ of the measures vs. energy demand $\left(\mathrm{kWh} / \mathrm{m}^{2}\right.$.year).

Figure 8 shows the map with the cost of the measures contemplated and assessed in order to achieve compliance with the limit of energy demand in each geographical zone and by orientation. It may be observed that a South facing orientation is, in the majority of cases, the most economical orientation; however, in the Mediterranean region (B3 N4, B3 W4, B3 E4, B4 N4, B4 W4, B4 E4, C3 N4, C4 N4) it was observed that other orientations are more advantageous. Generally, a West facing orientation has not proved to be the best one. This means that orientation is a factor which must be considered in order to achieve compliance with the regulations and in order to quantify the economic 
impact of the measures. Each climate zone has its own peculiarities; therefore, the measures to be chosen will be subject to climate zone and orientation.

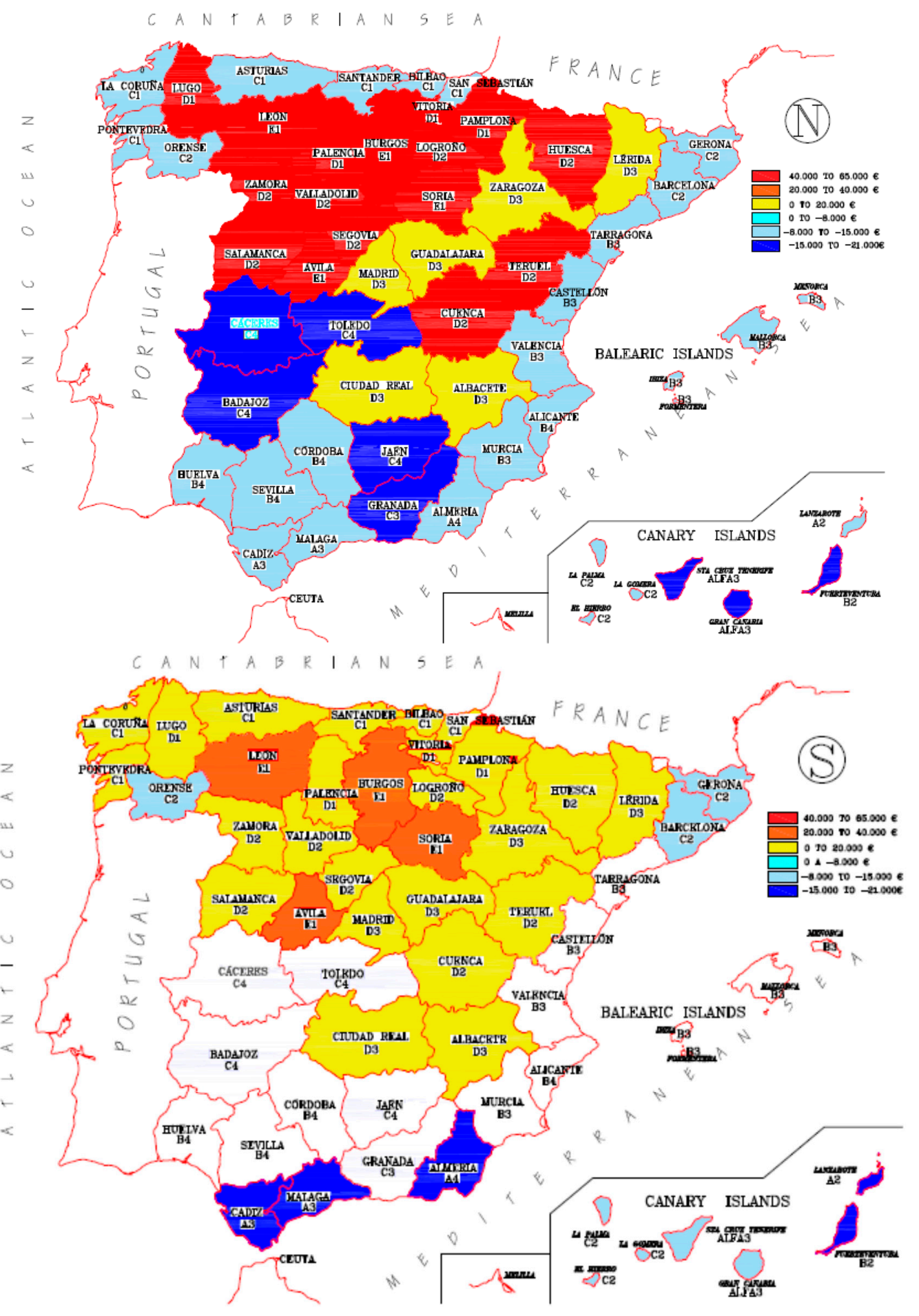

(a)

Figure 8. Cont. 


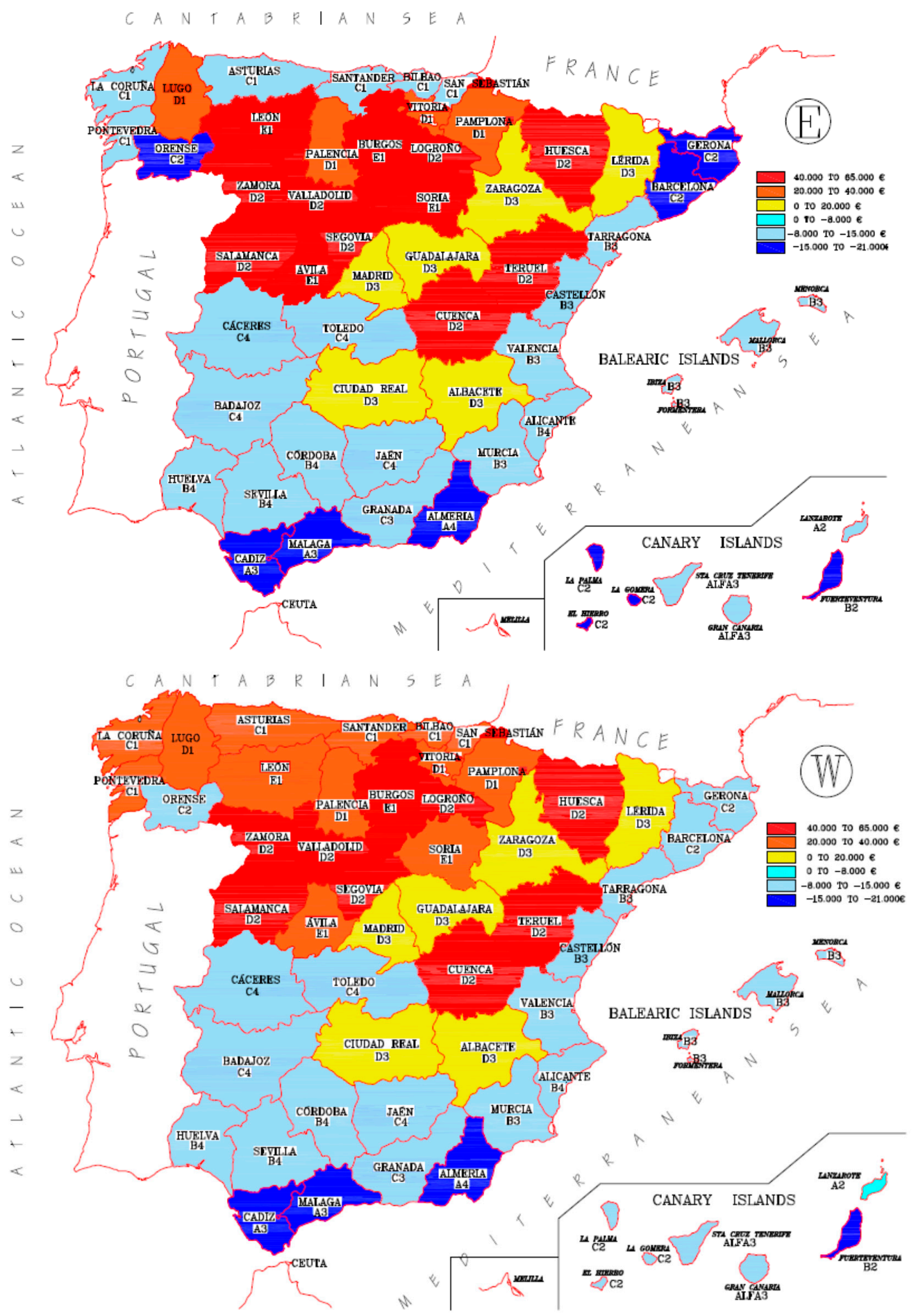

(b)

Figure 8. (a) Cost of the measures for orientation $(\mathrm{N}, \mathrm{S})$ and geographic zone. (b) Cost of the measures for orientation $(\mathrm{E}, \mathrm{W})$ and geographic zone.

Lastly, an analysis was carried out as on the measures employed (change of windows and glass, shade, insulation) in order to achieve compliance with energy demand by climate zone. One element that should be highlighted is that in very few cases (see Table 3), it was deemed unnecessary to make any changes to the surrounding walls and encasements. This indicates that, although there are climate zones which are similar, each case requires its own analysis. In Table 3, the proposed measures for compliance with the regulations may be observed in each case. 
Table 3. Measures proposed in each case (climatic zone and orientation).

\begin{tabular}{|c|c|c|c|c|c|}
\hline Climatic Zone & Orientation & Insulation & Improv_Glass & Shadow & Frame Change \\
\hline$\alpha 3$ & $\mathrm{~N}$ & RI & - & $x$ & - \\
\hline$\alpha 3$ & W & RI & - & $x$ & - \\
\hline$\alpha 3$ & $\mathrm{~S}$ & RI & - & $x$ & - \\
\hline$\alpha 3$ & $\mathrm{E}$ & RI & - & $x$ & - \\
\hline $\mathrm{A} 2$ & $\mathrm{~N}$ & RI & - & $x$ & - \\
\hline A2 & W & RI & $x$ & $X$ & - \\
\hline $\mathrm{A} 2$ & $\mathrm{~S}$ & RI & - & $x$ & - \\
\hline $\mathrm{A} 2$ & $\mathrm{E}$ & RI & - & $x$ & - \\
\hline $\mathrm{B} 2$ & $\mathrm{~N}$ & RI & - & $X$ & - \\
\hline $\mathrm{B} 2$ & W & RI & - & $x$ & - \\
\hline B2 & S & RI & - & $x$ & - \\
\hline B2 & $\mathrm{E}$ & RI & - & $x$ & - \\
\hline A3 & $\mathrm{N}$ & RI & $x$ & $x$ & - \\
\hline $\mathrm{A} 3$ & W & RI & - & $x$ & - \\
\hline $\mathrm{A} 3$ & $\mathrm{~S}$ & RI & - & - & - \\
\hline $\mathrm{A} 3$ & $\mathrm{E}$ & RI & - & $x$ & - \\
\hline A4 & $\mathrm{N}$ & RI & $x$ & $x$ & - \\
\hline A4 & $\mathrm{W}$ & RI & - & $x$ & - \\
\hline $\mathrm{A} 4$ & S & RI & - & - & - \\
\hline $\mathrm{A} 4$ & $\mathrm{E}$ & RI & - & $x$ & - \\
\hline B3 & $\mathrm{N}$ & RI & $x$ & - & - \\
\hline B3 & W & RI & $x$ & - & - \\
\hline B3 & $S$ & - & - & - & - \\
\hline B3 & $\mathrm{E}$ & RI & $x$ & - & - \\
\hline B4 & $\mathrm{N}$ & RI & $x$ & - & - \\
\hline B4 & W & RI & $x$ & - & - \\
\hline B4 & S & - & - & - & - \\
\hline B4 & $\mathrm{E}$ & RI & $x$ & - & - \\
\hline $\mathrm{C} 1$ & $\mathrm{~N}$ & RI & - & $x$ & $x$ \\
\hline $\mathrm{C} 1$ & W & Ins 2 & $x$ & - & - \\
\hline $\mathrm{C} 1$ & $S$ & Ins 1 & - & - & - \\
\hline $\mathrm{C} 1$ & $\mathrm{E}$ & RI & - & $x$ & $x$ \\
\hline $\mathrm{C} 2$ & $\mathrm{~N}$ & RI & $x$ & $x$ & - \\
\hline $\mathrm{C} 2$ & W & RI & - & $x$ & $x$ \\
\hline $\mathrm{C} 2$ & $S$ & RI & $x$ & - & $x$ \\
\hline $\mathrm{C} 2$ & $\mathrm{E}$ & RI & - & $x$ & $x$ \\
\hline $\mathrm{C} 3$ & $\mathrm{~N}$ & RI & - & - & - \\
\hline C3 & W & RI & $x$ & - & - \\
\hline $\mathrm{C} 3$ & $S$ & - & - & - & - \\
\hline $\mathrm{C} 3$ & $\mathrm{E}$ & RI & $x$ & - & - \\
\hline C4 & $\mathrm{N}$ & RI & - & - & - \\
\hline C4 & W & RI & $x$ & - & - \\
\hline $\mathrm{C} 4$ & S & - & - & - & - \\
\hline $\mathrm{C} 4$ & $\mathrm{E}$ & RI & $x$ & - & - \\
\hline D1 & $\mathrm{N}$ & Ins 4 & $x$ & - & $x$ \\
\hline D1 & W & Ins 2 & $x$ & - & - \\
\hline D1 & S & Ins 1 & $X$ & - & $x$ \\
\hline D1 & $\mathrm{E}$ & Ins 2 & $X$ & - & - \\
\hline D2 & $\mathrm{N}$ & Ins 4 & $x$ & - & - \\
\hline D2 & W & Ins 4 & $x$ & - & - \\
\hline D2 & S & Ins 1 & $x$ & - & $x$ \\
\hline D2 & $\mathrm{E}$ & Ins 4 & - & - & $X$ \\
\hline D3 & $\mathrm{N}$ & Ins 1 & - & - & - \\
\hline D3 & W & Ins 1 & - & - & $x$ \\
\hline D3 & $S$ & - & $x$ & - & $X$ \\
\hline D3 & $\mathrm{E}$ & Ins 1 & - & - & $x$ \\
\hline E1 & $\mathrm{N}$ & Ins 5 & $x$ & - & $x$ \\
\hline E1 & W & Ins 2 & $x$ & - & $x$ \\
\hline E1 & $\mathrm{S}$ & Ins 2 & $x$ & - & $x$ \\
\hline E1 & $\mathrm{E}$ & Ins 4 & $x$ & - & $x$ \\
\hline
\end{tabular}


The most common measure has been the replacement of the insulation, in more than half of the occasions by removing it completely (38 cases) and in the rest of the cases, it was necessary to improve it. Only in a very few cases was it deemed unnecessary to replace the insulation; this was only in mild climate zones and with a South facing orientation. The second measure in order of importance was the improvement of the windows and glass, which was proposed in nearly half of the cases, especially in colder climate zones, with the exception of zone $\alpha$ where it did not prove necessary. Another of the measures that has been frequently used was the shading of the façade, above all in warm zones, with the exception of zones D and $\mathrm{E}$ where it was not necessary. The least used proposal was changes to carpentry.

There is much work focused on reducing the solar gains from office buildings, as they have traditionally been designed to maximize natural lighting during the working hours.

The windows orientation is key to minimising the solar gains, as highlighted by several studies [37-40] which similarly investigated the application of shading devices. This measure implies a slight energy consumption increase during the winter months, although the annual load is reduced [41]. For example, Lau et al. [38] suggested the benefits from adding shading solutions to the East and West glazed orientated facades on a high-rise office building. Additionally, research by Raheem et al. [40] concluded that North and North East orientated windows reduced the annual energy demand in offices, and that shading devices were most effective if their transmittance was below $30 \%$ and were externally placed, regardless of the orientation.

In cooling-dominant climates, low-e glazing was deemed to be the best window solution when considering both thermal and daylighting performance in a 20-floor high-rise office building [42]. For shading options, overhang shading performed better than internal blinds, due to the blinds' adjustability key. Window performances were analysed depending on orientation. The blinds reflectivity also affected the performance, and showed that higher reflectivity was more effective. This solution was reported to possible enhance uncomfortable conditions such as overheating and glare [43]. Double Skin Facades (DSF) in office buildings within hot climate zones', on the other hand, offer an interesting solution to control the solar input [37].

The effect of building orientation has also a grounded impact on energy consumption $[43,44]$. For example, a study looking for sustainable facade design for zero energy buildings in the tropics suggested that optimal orientated shallow buildings provided the highest electricity reduction potential [44].

There are also more innovative constructive solutions that fall outside of the focus of this article. For example, an innovative facade solution, the aerogel granulated glazing facade, provided solar gains reduction and consequently reduced cooling demand [45].

The criteria used for warmer zones were, in first place, a reduction in insulation, given that this helps to comply with the requirements of CTE DB HE-1, and in addition, reduces economic costs. After this, a change in the windows and glass was explored and lastly the addition of window slats was examined.

Regarding the inclusion of window slats, they were installed first on the West facing facade, and later, on the East facing facade. In cases where, having installed slats on the East and West facing facades, insulation has been removed from the flooring and solar control glass has been installed, but the limit of energy demand for the building has not been complied with, the minimum number of possible slats would be installed on the main facade. The reason for this stems from the fact that using slats has a negative visual impact, and more so when it comes to large good quality windows. In cases where the use of window slats has been required in the main façade with its consequential visual impact, the improvement of the windows and glass has been set aside, given that the installation of window slats has a greater effect on reducing energy demand and thus the financial cost of modifying the windows and glass is avoided.

By way of an example, the process followed for a specific climate zone and orientation is described; in this case, it corresponds to a non-peninsular climate zone on the islands. The climate in these zones 
is very different to that which exists on the peninsula. The zones located on the Canary Islands, with an altitude of between 350 and $750 \mathrm{~m}$, are considered as being climate zone A2. In non-peninsular areas, in general, a change of frame was rejected because it would increase energy demand; thus, a metallic frame was used. In this zone, as in zone A3, it has been necessary to implement the following measures: remove insulation in the flooring, reduce the prefabricated concrete panel and install slats in the façade. Table 4 shows a summary of the results achieved for the proposed improvements (the intermediate results for the changing of each of the 10 windows, $j=7$ to $j=15$ are not shown). Of the 60 cases analysed, it can be stated that the combination $\mathrm{A} 2 \mathrm{~W}_{1}$ has proved the most difficult, given that of all the warm climate zones, it is the only one where all proposed improvements were necessary. It was not only necessary to remove the insulation, but the installation of window slats on all windows of the building was also required, giving the building a visual aspect that was not originally planned and in addition the glass in all the windows would have to be changed to "Planistar" with solar control $\left(\mathrm{A} 2 \mathrm{~W}_{16}\right)$.

Table 4. Simulations for measures proposed in zone A2 W.

\begin{tabular}{ccc}
\hline Id Simulation & Measurements Proposed & Energy Demand $\mathbf{( k W h} / \mathbf{m}^{\mathbf{2}} /$ Year) \\
\hline $\mathrm{A} 2 \mathrm{~W}_{1}$ & Initial situation & 25.93 \\
$\mathrm{~A} 2 \mathrm{~W}_{2}$ & Retire insulation & 23.45 \\
$\mathrm{~A} 2 \mathrm{~W}_{3}$ & Retire insulation + glass & 22.82 \\
$\mathrm{~A} 2 \mathrm{~W}_{4}$ & Retire insulation + West shadows & 22.66 \\
$\mathrm{~A} 2 \mathrm{~W}_{5}$ & Retire insulation + West and East shadows & 22.43 \\
$\mathrm{~A} 2 \mathrm{~W}_{6}$ & Retire insulation + West and East shadows + glass & 21.78 \\
$\mathrm{~A} 2 \mathrm{~W}_{16}$ & Retire insulation + West and East shadows + 10 & 18.01 \\
\hline
\end{tabular}

In Figure 9, mosaic plots measurements per zones are analysed. Mosaic plots were introduced as a means of visualising contingency tables and consist of groups of rectangular tiles [46]. Each tile corresponded to one cell from a contingency table. Its area was proportional to the size of the cell, and its shape and location were determined during the construction process. Mosaics are area-based graphics; the area of each tile is proportional to the cell size of the corresponding contingency table. However, the overall number of observations was not displayed in a mosaic plot. It is therefore more relevant to discuss percentages or probabilities in relation to mosaic plots rather than actual cell sizes. Tile sizes should always be interpreted in relation to the sizes of other tiles.

Regarding the improvement of glass, in this mosaic plot the widths of the boxes are proportional to the percentage of cases without or with improvement in glass, respectively. In Zone $\alpha$, glass has not been improved in $100 \%$ of cases. In contrast, in zones A, B, C and D, 25\%, 50\%, 44\%, $67 \%$ and $100 \%$ of cases glass has been improved, respectively.

This analysis carried out for each one of the zones is of interest because it provide guidelines for selecting construction elements in order to comply with energy demand limitation according to climate zone, as is shown in Figure 9. For example, in the case of zone $\alpha$, the proposals will be to remove insulation and install shading. However, in zone E, the proposal would lean towards changing the windows and glass and carpentry and improving insulation subject to orientation.

The quantitative influence on the starting situation of the different measures adopted in isolation (without considering interactions between them) was analysed (Table 5).

In this case, the measure that has provided the greatest savings with respect to the initial situation was Ins 4 (Ins 4), reaching an improvement of 17\% in climate zone D1 O6. In general, the improvements in insulation have had significant savings percentages, being $5 \%, 8 \%, 9 \%, 11 \%$ and $10 \%$ for insulation improvements 1, 2, 3, 4 and 5, respectively.

The next step in order of improvement has been to eliminate insulation (RI) with an average saving of 5\%. In contrast, measures considered in isolation such as replacing door and window frames 
and changing glass, provide savings of less than $3 \%$, and have therefore been used in a complementary manner to the previous ones.



(A) Insulation

Improv_Glass

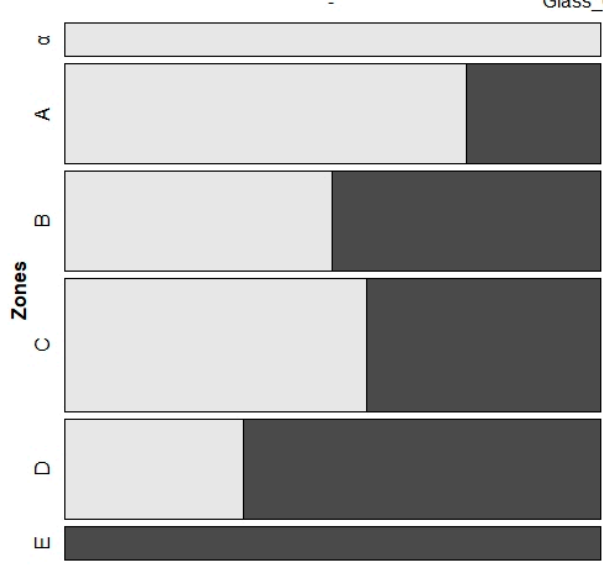

(C) Improvement Glass

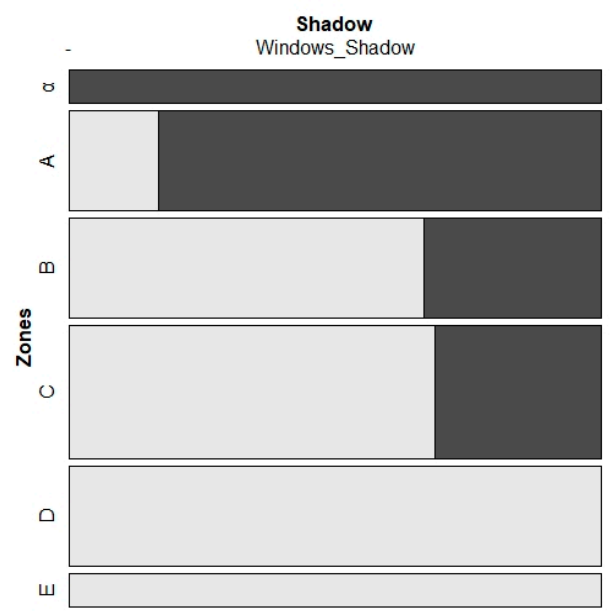

(B) Shadow

Framechange

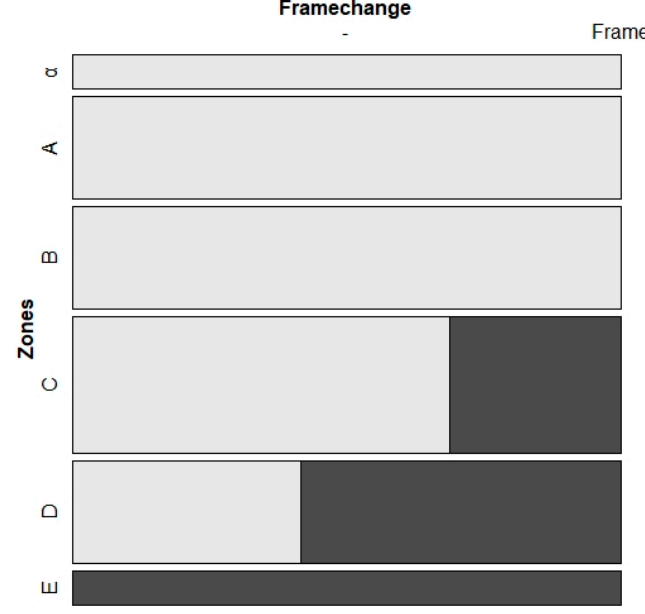

(D) Change Frame

Figure 9. Mosaic graph for each measurement (Insulation, Shadow, Glass and Frame) and climatic zone.

Table 5. Savings in energy demand compared to the initial situation introduced by the various measures analysed in isolation.

\begin{tabular}{ccccc}
\hline Improvement Measure & $\begin{array}{c}\text { Average } \\
\text { Savings }\end{array}$ & $\begin{array}{c}\text { Number of Times } \\
\text { Used in Isolation }\end{array}$ & $\begin{array}{c}\text { Maximum } \\
\text { Savings }\end{array}$ & $\begin{array}{c}\text { Minimum } \\
\text { Savings }\end{array}$ \\
\hline Window and doorframe & $1 \%$ & 4 & $2 \%$ & $0 \%$ \\
Insulation improvement 1 (Ins 1) & $5 \%$ & 28 & $8 \%$ & $0 \%$ \\
Insulation improvement 2 (Ins 2) & $8 \%$ & 19 & $13 \%$ & $1 \%$ \\
Insulation improvement 3 (Ins 3) & $9 \%$ & 11 & $13 \%$ & $3 \%$ \\
Insulation improvement 4 (Ins 4) & $11 \%$ & 9 & $17 \%$ & $2 \%$ \\
Insulation improvement 5 (Ins 5) & $10 \%$ & 1 & $10 \%$ & $10 \%$ \\
Remove insulation (RI) & $5 \%$ & 40 & $10 \%$ & $-1 \%$ \\
Door and window glazing & $2 \%$ & 5 & $2 \%$ & $2 \%$ \\
\hline
\end{tabular}




\section{Conclusions}

The aim of this work has been to analyse the behaviour of the energy demand of a low-rise office building using HULC software to verify compliance with regulations in Spain. The variables considered have been climate zone, building orientation and facades and encasement types typical of this type of construction. Amongst the principal conclusions of the study, the following should be highlighted. In general, a South facing orientation has been the most favourable, as it requires a lower number of simulations in order to comply with regulatory levels. The least conflictive climate zones have been those of $\mathrm{B} 3$ and $\mathrm{B} 4$ and the most conflictive zones $\mathrm{C} 1$ and $\mathrm{C} 2$. In general, in the warm and temperate climate zones (A, B and $\mathrm{C}$ ) the proposed measures have meant an economic saving with respect to the original plans while in cold climate zones ( $\mathrm{D}$ and $\mathrm{E}$ ), extra costs are required.

The measure used most frequently has been to improve or remove the insulation and the second most common measure has been the improvement of windows and glass, especially in colder climate zones. The shading of facades has also been frequently used in warm zones, while other measures such as changes in carpentry have been used very rarely.

The measure that has provided the greatest savings with respect to the initial situation, without considering interactions between them, has been Ins 4 (Ins 4), reaching an improvement of $17 \%$ in climate zone D1 O6. In general, the improvements in insulation, including its removing, have had caused significant savings percentages of between $5 \%$ and $11 \%$. In contrast, measures such as replacing door and window frames and changing glass provide savings of less than $3 \%$, and have therefore been used in a complementary manner to the previous ones.

This analysis carried out provides the project architect or engineer with quick guidelines for selecting construction elements in order to comply with energy demand limitations subject to the climate zone of the site.

The main limitation of this study lies in the fact that the energy consumption of the heating, ventilation and air conditioning (HVAC) systems of the building and their relationship with the energy classification of the same were not analysed. Situations might arise where in order to achieve a determined energy classification, it may be necessary to compensate for the energy consumption of the installations with improvements to the facades and encasements of the building. This behaviour will be analysed in future lines of study.

Author Contributions: J.L.F.-B. and J.-L.V. conceived and designed the experiments. M.Á.G.-G. ran the experiments and generated the data. J.L.F.-B. and P.F.-G. analysed the state of the art literature and developments. J.-L.V. and P.F.-G. analysed the data and obtained the results. J.L.F.-B., J.-L.V. and P.F.-G. wrote the paper and revised the final version of the document. All authors have read and agreed to the published version of the manuscript.

Funding: This research received no external funding.

Conflicts of Interest: The authors declare no conflict of interest.

\section{References}

1. Pérez-Lombard, L.; Ortiz, J.; Pout, C. A review on buildings energy consumption information. Energy Build. 2008, 40, 394-398. [CrossRef]

2. IEA. Energy Efficiency in Europe. Overview of Policies and Good Practices; International Energy Agency: Paris, France, 2014.

3. IEA. Technology Roadmap. Energy Efficient Building Envelopes; International Energy Agency: Paris, France, 2014.

4. IEA. Technology Roadmap. Energy Efficient Buildings. Heating and Cooling Equipment; International Energy Agency: Paris, France, 2014.

5. European Commission Energy Roadmap 2050. 2011. Available online: https://www.google.com.hk/url?sa=t\&rct= $j \& q=\& e s r c=s \& s o u r c e=w e b \& c d=\& v e d=2$ ahUKEwiD95W5-qrqAhVP62EKHaYLCFAQFjADegQIARAB\& url=https\%3A\%2F\%2Fec.europa.eu\%2Fenergy\%2Fsites\%2Fener\%2Ffiles\%2Fdocuments\%2F2012_energy_ roadmap_2050_en_0.pdf\&usg=AOvVaw3tfjm-IvZt9fXrnZuvpohw (accessed on 20 June 2020).

6. European Comission Climate Strategies \& Targets. Available online: https://ec.europa.eu/clima/policies/ strategies/2030_en (accessed on 1 January 2020). 
7. European Comission Climate Negotations. Available online: https://ec.europa.eu/clima/policies/international/ negotiations/paris_en (accessed on 1 January 2020).

8. European Comission. Directive 2002/91/EC of the European Parliament and of the Council of 16 December 2002 on the Energy Performance of Buildings. Off. J. Eur. Union 2002, 0065-0071.

9. European Comission. Directive 2010/31/EU of the European Parliament and of the Council of 19 May 2010 on the Energy Performance of Buildings. Off. J. Eur. Union 2010, 18, 13-15.

10. European Comission. Directive 2012/27/EU of European Parliament and of the Council of 25 October 2012 on Energy Efficiency, Amending Directives 2009/125/EC and 2010/30/EU and Repealing Directives 2004/8/EC and 2006/32/EC. Off. J. Eur. Union 2012, 315, 1-56.

11. European Union Directive (EU). 2018/844 of the European Parliament and of the Council of 30 May 2018 Amending Directive 2010/31/EU on the Energy Performance of Buildings and Directive 2012/27/EU on Energy Efficiency. Available online: https://eur-lex.europa.eu/legal-content/EN/TXT/PDF/?uri=CELEX: 32018L0844\&from=EN (accessed on 20 June 2020).

12. Kurnitski, J.; Saari, A.; Kalamees, T.; Vuolle, M.; Niemelä, J.; Tark, T. Cost optimal and nearly zero (nZEB) energy performance calculations for residential buildings with REHVA definition for nZEB national implementation. Energy Build. 2011, 43, 3279-3288. [CrossRef]

13. Aparicio Ruiz, P.; Guadix Martín, J.; Salmerón Lissén, J.M.; Sánchez De La Flor, F.J. An integrated optimisation method for residential building design: A case study in Spain. Energy Build. 2014, 80, 158-168. [CrossRef]

14. Tourism and Digital Agenda Plan Nacional de Acción de Eficiencia Energética 2017-2020. 2017. Available online: https://ec.europa.eu/energy/sites/ener/files/documents/es_neeap_2017_es.pdf (accessed on 20 June 2020).

15. Guía de Ahorro y Eficiencia Energética en Oficinas. 2008. Available online: http://www.officinaseficientes.es/ docs/guia_OFF.pdf (accessed on 20 June 2020).

16. Crawley, D.B.; Hand, J.W.; Kummert, M.; Griffith, B.T. Contrasting the capabilities of building energy performance simulation programs. Build. Environ. 2008, 43, 661-673. [CrossRef]

17. Pérez-Andreu, V.; Aparicio-Fernández, C.; Martínez-Ibernón, A.; Vivancos, J.-L. Impact of climate change on heating and cooling energy demand in a residential building in a Mediterranean climate. Energy 2018, 165, 63-74. [CrossRef]

18. Herrando, M.; Cambra, D.; Navarro, M.; de La Cruz, L.; Millán, G.; Zabalza, I. Energy Performance Certification of Faculty Buildings in Spain: The gap between estimated and real energy consumption. Energy Convers. Manag. 2016, 125, 141-153. [CrossRef]

19. Sinacka, J.; Ratajczak, K. Analysis of selected input data impact on energy demand in office building-case study. MATEC Web Conf. 2018, 222. [CrossRef]

20. Mikulik, J. Energy demand patterns in an office building: A case study in Kraków (Southern Poland). Sustainability 2018, 10, 2901. [CrossRef]

21. The Technical Building Code; Ministry of Development and the Spanish Research Scientific Council (CSIC): Madrid, Spain, 2006.

22. LIDER and Spanish Technical Building Code; Ministry of Housing and Institute for the Diversification and Saving of Energy: Madrid, Spain, 2013.

23. Aparicio Ruiz, P.; Sánchez de La Flor, F.; Molina Felix, J.; Salmerón Lissén, J.; Guadix Martín, J. Applying the HVAC systems in an integrated optimization method for residential building's design. A case study in Spain. Energy Build. 2016, 119, 74-84. [CrossRef]

24. Royal Decree 235/2013, of 5th April, Agreeing to the Procedure Basic for the Certification of the Energy Efficiency of Buildings. Available online: https://www.boe.es/buscar/pdf/2013/BOE-A-2013-3904consolidado.pdf (accessed on 20 June 2020).

25. Unified Tool LIDER-CALENER (HULC-Tool). 2017. Available online: https://veredes.es/blog/en/herramientaunificada-lider-calener-hulc/ (accessed on 20 June 2020).

26. Rosselló-Batle, B.; Ribas, C.; Moià-Pol, A.; Martínez-Moll, V. An assessment of the relationship between embodied and thermal energy demands in dwellings in a Mediterranean climate. Energy Build. 2015, 109, 230-244. [CrossRef]

27. Sánchez-Ramos, J.; Guerrero-Delgado, M.C.; Álvarez-Domínguez, S.; Molina-Félix, J.L.; Sánchez de la Flor, F.J.; Tenorio-Rios, J. Systematic simplified simulation methodology for deep energy retrofitting towards nze targets using Life Cycle Energy Assessment. Energies 2019, 12, 3038. [CrossRef] 
28. Support Document of the DB HE1 for Thermal Bridges (DA DB-HE/3); Spanish Ministry of Development: Madrid, Spain, 2015.

29. Basic Document HE 1 for Energy Conservation (DB HE); Spanish Ministry of Development: Madrid, Spain, 2013.

30. Royal Decree 1027/2007, of 20th July, Approving the Regulations on Thermal Installations in Buildings; Spanish Ministry of Presidency: Madrid, Spain, 2007.

31. Catalogue of Constructive Elements of the TBC 2011. Available online: https://itec.cat/cec/ (accessed on 20 June 2020).

32. Construction Technology of Catalonia (Instituto de Tecnología de la Construcción: ITec). Available online: https://en.itec.cat/ (accessed on 20 June 2020).

33. Ministry of Development Support Document of the DB HE1 for the calculation of Characteristic Parameters of the Building Envelope (DA DB-HE/1) 2015. Available online: https://www.codigotecnico.org/images/stories/ pdf/ahorroEnergia/DA_DB-HE-1_Calculo_de_parametros_caracteristicos_de_la_envolvente.pdf (accessed on 20 June 2020).

34. Condiciones de Aceptación de Procedimientos Alternativos a LIDER y CALENER. 2009. Available online: https://www.idae.es/publicaciones/condiciones-de-aceptacion-de-procedimientos-alternativos-lidery-calener (accessed on 20 June 2020).

35. Design Builder Software, ANSI/ASHRAE Standard 140-2004 Building Thermal Envelope and Fabric Load Tests 2006. Available online: http://www.designbuilder.co.uk/documents/ANSI_ASHRAE.pdf (accessed on 20 June 2020).

36. Instituto Valenciano de Edificación (IVE) Instituto Valenciano de Edificación (IVE). Database 2019. Available online: https://www.five.es/productos/herramientas-on-line/visualizador-2019/ (accessed on 20 June 2020).

37. Haase, M.; Marques da Silva, F.; Amato, A. Simulation of ventilated facades in hot and humid climates. Energy Build. 2009, 41, 361-373. [CrossRef]

38. Lau, A.K.K.; Salleh, E.; Lim, C.H.; Sulaiman, M.Y. Potential of shading devices and glazing configurations on cooling energy savings for high-rise office buildings in hot-humid climates: The case of Malaysia. Int. J. Sustain. Built Environ. 2016, 5, 387-399. [CrossRef]

39. Al-ajmi, F.F.; Hanby, V.I. Simulation of energy consumption for Kuwaiti domestic buildings. Energy Build. 2008, 40, 1101-1109. [CrossRef]

40. Raheem, A.A.; Issa, R.R.; Olbina, S. Solar transmittance analysis of different types of sunshades in the Florida climate. Build. Simul. 2014, 7, 3-11. [CrossRef]

41. Valladares-Rendón, L.G.; Lo, S.L. Passive shading strategies to reduce outdoor insolation and indoor cooling loads by using overhang devices on a building. Build. Simul. 2014, 7, 671-681. [CrossRef]

42. Huang, Y.; Niu, J.; Chung, T. Comprehensive analysis on thermal and daylighting performance of glazing and shading designs on office building envelope in cooling-dominant climates. Appl. Energy 2014, 134, $215-228$. [CrossRef]

43. Ng, P.K.; Mithraratne, N.; Kua, H.W. Energy analysis of semi-transparent BIPV in Singapore buildings. Energy Build. 2013, 66, 274-281. [CrossRef]

44. Haase, M.; Amato, A. Sustainable façade design for zero energy buildings in the tropics. In Proceedings of the PLEA2006-The 23rd Conference on Passive and Low Energy Architecture, Geneva, Switzerland, 6-8 September 2006.

45. Ihara, T.; Gao, T.; Grynning, S.; Jelle, B.P.; Gustavsen, A. Aerogel granulate glazing facades and their application potential from an energy saving perspective. Appl. Energy 2015, 142, 179-191. [CrossRef]

46. Hofmann, H. Mosaic plots and their variants. In Handbook of Data Visualization; Springer: Berlin/Heidelberg, Germany, 2008; pp. 617-642.

(C) 2020 by the authors. Licensee MDPI, Basel, Switzerland. This article is an open access article distributed under the terms and conditions of the Creative Commons Attribution (CC BY) license (http://creativecommons.org/licenses/by/4.0/). 